\title{
Multidrug-resistant Gram-negative bacilli producing oxacillinases and Metallo- $\beta$-lactamases isolated from patients in intensive care unit - Annaba hospital - Algeria (2014-2016)
}

\author{
Soumaya Toumi ${ }^{1,2}$, Saida Meliani ${ }^{1,2}$, Kamel Amoura ${ }^{3}$, Ahmed Rachereche ${ }^{4}$, Mahfoud Djebien ${ }^{4}$, Abdelghani Djahoudi ${ }^{*}$ \\ ${ }^{1}$ Department of Pharmacy, Faculty of Medicine, Laboratory of Microbiology, University Badji Mokhtar, Annaba, Algeria. \\ ${ }^{2}$ Department of Biochemistry, Faculty of Sciences, University Badji Mokhtar, Annaba, Algeria. \\ ${ }^{3}$ University Hospital Dorban, Laboratory Central of Microbiology, Annaba, Algeria. \\ ${ }^{4}$ University Hospital Ibn Rochd, Resuscitation-Anesthesia Service, Annaba, Algeria. \\ ${ }^{5}$ Laboratory of Microbiology, Department of Pharmacy, Faculty of Medicine, University Badji Mokhtar, Annaba, Algeria.
}

\begin{tabular}{|c|c|}
\hline ARTICLE INFO & ABSTRACT \\
\hline $\begin{array}{l}\text { Article history: } \\
\text { Received on: } 07 / 03 / 2018 \\
\text { Accepted on: } 09 / 05 / 2018 \\
\text { Available online: } 30 / 07 / 2018\end{array}$ & $\begin{array}{l}\text { This study aims to investigate the prevalence and genes encoding for carbapenemases of multidrug-resistant Gram- } \\
\text { negative bacilli isolated from the intensive care unit in the hospital of Annaba city, Algeria, over a period of } 18 \text { months. } \\
\text { The isolates were identified using API20E, API } 20 \mathrm{NE} \text { and confirmed by Microscan WalkAway } 96 \text {. Antimicrobial } \\
\text { susceptibility testing was determined by the disk diffusion method according to clinical and laboratory standards } \\
\text { institute guidelines. Carbapenemases production was tested using Hodge and imipenem-EDTA Combined Disc }\end{array}$ \\
\hline $\begin{array}{l}\text { Key words: } \\
\text { Gram-negative bacilli, } \\
\text { Metallo- } \beta \text {-lactamases, } \\
\text { multidrug resistant, } \\
\text { Oxacillinases, Intensive care } \\
\text { unit. }\end{array}$ & $\begin{array}{l}\text { tests. Carbapenemases genes were established by Polymerase chain reaction and confirmed by sequencing. } 35.52 \% \\
\text { of } 152 \text { isolates were multidrug-resistant. The majority belong to Enterobacteriaceae }(75.92 \%) \text { followed by non- } \\
\text { fermentative Gram-negative bacilli }(24.07 \%) \text {. The Enterobacteriaceae revealed high resistance to third generation } \\
\text { cephalosporin, with the production of cephalosporinases }(36.58 \%) \text { and/or extended-spectrum } \beta \text {-lactamases }(34.14 \%) \text {. } \\
\text { For non-fermentative Gram-negative bacilli, they showed increased resistance to carbapenems, fluoroquinolones, and } \\
\text { aminoglycosides. Fifteen of the MDR strains were resistant to carbapenems, } 10 \text { of them were positives for Metallo- } \\
\beta \text {-lactamases and carbapenemases by phenotypic methods. The PCR results showed the presence of bla } a_{\text {VIM-2 }} \text { gene in } \\
\text { two Pseudomonas aeruginosa, bla } \\
\text { surveillance of the resistance in this unit is necessary to prevent any therapeutic impasse. }\end{array}$ \\
\hline
\end{tabular}

\section{INTRODUCTION}

Infections in intensive care units (ICUs) are becoming not only recurrent but also increasingly complicated. They cause high morbidity and mortality over the world. These infections are usually caused by multi-drug resistant bacteria (MDR), especially Gram negative-bacilli (GNB), where their prevalence in Algeria and all over the world increases in a worrying way and represents a serious public health problem (Baba Ahmed and Arlet, 2014).

\section{"Corresponding Author}

Pr. Abdelghani Djahoudi, Faculty of Medicine, BP 205, Zaafrania

Street, University Badji Mokhtar, Annaba 23000, Algeria.

E-mail:adjahoudi@yahoo.fr
The most MDR bacteria involved are the GNB represented by Enterobacteriaceae; they are frequently isolated from hospitalized patients (Kaye and Pogue, 2015). Pseudomonas aeruginosa and Acinetobacter baumannii appears as the major agent causing infections in intensive care units, especially for immunocompromised patients. Their ability to develop resistance to antimicrobial agents makes treatment of these infections ever more difficult (McGowan, 2006). The infections caused by these MDR bacteria are essentially related to the frequent use of invasive procedures.

The most common resistance mechanism is the secretion of extended-spectrum $\beta$-lactamases (ESBLs) (Kaye and Pogue, 2015); these enzymes confer a resistance to the majority of $\beta$-lactams, posing then a high risk of therapeutic failure and the 
emergence of MDR. In this case, carbapenems are prescribed for the reason of their stability to most natural or acquired $\beta$-lactamases. However, the resistance for this class of antibiotics has taken place all over the world, with the emergence of Enterobacteriaceae producing carbapenemases (EPC) (Poirel et al., 2013), carbapenem-resistant $P$. aeruginosa and A. baumannii. Carbapenem resistance in non-fermentative Gram-negative bacilli (NF-GNB) is due to a variety of drug resistance mechanisms such as the loss of porins OprD and efflux pumps. The most common mechanism is the acquisition of genes encoding for carbapenemases particularly, Metallo- $\beta$-lactamases (MBLs) of $P$. aeruginosa where the most common genes reported are VIM, IMP, GIM, FIM, and SPM (Rodriguez-Martinez, 2009). The $b l a_{V I M-2}$ is the dominant Metallo- $\beta$-lactamase in North Africa and all over the world (Hashem et al., 2017). The common oxacillinases for A. baumannii are OXA-23, 24, 58 of which OXA-23 is the most frequent. These enzymes have been reported in clinical isolates from different hospitals in western and eastern Algeria and in other parts of the world (Touati et al., 2012; Mohajeri et al., 2017; Pogue et al., 2013).

GNB represents one of the main causes of serious infections in the hospitals of Annaba city. Their resistance to antibacterial agents is being increasingly complicated. The aim of the present study is to investigate the prevalence of Gram-negative bacilli multidrug-resistant (MDR-GNB) and characterization of genes encoding for carbapenemases isolated from the intensive care unit (department of anesthesia-resuscitation) of Ibn Rochd hospital, Annaba, Algeria, over a period of 18 months.

\section{MATERIALS AND METHODS}

\section{Collected data}

The prospective study on MDR-GNB, isolated from various specimens was performed over 18 months (December 2014 to May 2016) from distal protected sampling (DPS), pus, rectal swab (RS) and urine taken from patients hospitalized in the intensive care unit (Ibn Rochd hospital, Annaba). The information about patients has been obtained from the patient medical records including age, sex, anterior hospitalization, clinical signs, hospitalization period and the presence or absence of risk factors.

\section{Identification and antibiotic susceptibility testing}

The GNB isolates were identified using API20E,API20NE galleries (Bio-Mérieux France) and Microscan WalkAway 96 plus (Siemens) automate. Antibiotic susceptibility was determined using the Muller-Hinton agar diffusion method, according to the recommendations of Clinical and Laboratory Standards Institute (CLSI). Eleven antibiotics were tested for Enterobacteriaceae: amoxicillin, amoxicillin/clavulanic acid, cefotaxime, ceftriaxone, aztreonam, ceftazidime, imipenem, ertapenem, gentamycin, amikacin, and ciprofloxacin. For NF-GNB, eleven antibiotics were also tested: piperacillin, cefotaxime, ceftriaxone, ceftazidime, aztreonam, imipenem, gentamycin, amikacin, ciprofloxacin, ticarcillin, ticarcillin/clavulanic acid.

The determination of minimum inhibitory concentrations (MIC) were carried out by automated Microscan WalkAway 96 plus, using plates adapted to each kind of bacteria. The MIC of ertapenem and imipenem were determined in solid media, following the CLSI recommendations.

All the isolates found simultaneously resistant to two or more antibiotics of different families are considered as multidrugresistant (according to Center for Disease Control (CDC) criteria), and are included in this study.

\section{Phenotypic detection for extended-spectrum $\beta$-lactamases (ESBL)}

The ESBL production was detected by the double-disc synergy test (DDST) and by a cloxacillin test for strains that are resistant to cefotaxime, ceftazidime and/or aztreonam. In DDST, a disc of amoxicillin/clavulanic acid (AMC $30 \mu \mathrm{g}$ ) was placed in the center of MHA at $30 \mathrm{~mm}$ distance to ceftazidime (CAZ $30 \mu \mathrm{g}$ ) and cefotaxime (CTX $30 \mu \mathrm{g}$ ). ESBL production was detected by the appearance of keyhole effect between AMC disc and C3G (Drieux et al., 2008). The cloxacillin test has been also done on MHA supplemented with 250 $\mathrm{mg} / \mathrm{L}$ of cloxacillin, in order to detect any ESBL eventually masqued by AmpC cephalosporinase (Drieux et al., 2008).

\section{Phenotypic detection of carbapenemases and metallo- $\beta$ - lactamases (MBLs)}

All the isolates resistant to imipenem and ertapenem were subjected to modified Hodge test (MHT) as was described by CLSI guidelines. A dilute suspension of $1 / 10$ of $E$. coli ATCC 25922 (0.5 McFarland) was prepared and inoculated on MHA. An imipenem disk $(10 \mu \mathrm{g})$ is placed in the center of the test area. Test organism was streaked in a straight line from the edge of the disk to the edge of the plate. The plate was incubated at $35^{\circ} \mathrm{C}$ for 16-24 h. MHT Positive test showed a cloverleaf-like indentation of the E. coli 25922 growing along the test organism growth streak within the disk diffusion zone.

The combined-disc test using imipenem-EDTA was adopted for the detection of metallo- $\beta$-lactamases as previously described by Esther et al. (2017). Two imipenem discs $(10 \mu \mathrm{g})$ were placed $25 \mathrm{~mm}$ apart on an MHA plate, $10 \mu \mathrm{L}$ of EDTA was added to one of them. The plate was incubated $16-24 \mathrm{~h}$ at $35^{\circ} \mathrm{C}$. An increase in the inhibition zone diameter greater than $6 \mathrm{~mm}$ around the imipenem-EDTA disc compared with that of the imipenem disc alone was considered positive for MBL production.

\section{Molecular search for genes encoding carbapenemases and their sequencing}

The search for genes encoding for carbapenemases was realized by real-time Polymerase Chain Reaction (PCR) and standard PCR, using primers and probes specific to various reference strains. The amplified PCR products obtained have been sequenced using Big Dye terminator chemistry on an ABI 3130XL automated sequencer (Applied Biosystems, Foster City, California, United States). The nucleotide and deduced protein sequences were analyzed using the ARG-ANNOT (Antibiotic Resistance Gene-ANNOTation) (Gupta et al., 2014).

\section{RESULTS AND DISCUSSION}

\section{Bacterial isolates}

A total of 152 GNB have been isolated (13 to 81 years, mean age $=39.5$ ). The identification allowed to class 122 strains 
in the family of Enterobacteriaceae $(80.26 \%)$ and 30 NF-GNB $(19.73 \%)$. More than $35 \%$ of the isolates $(n=54)$ were MDR. This result is comparable to that obtained in India (33.5\%) (Silpi et al., 2016), but higher than the results obtained in the University Hospital of Marrakech, Morocco (20\%) (Arsalane et al., 2010). In France, many hospitals reported a high prevalence of MDR, especially in intensive care units since the 1990s (Régnier, 1996). These MDRs bacteria were isolated from urine ( $n=18,33.33 \%)$, various pus $(n=21,38.88 \%), \operatorname{RS}(n=8,14.81 \%)$ and DPS $(n=$ $7,12.96 \%)$.

The high prevalence of MDR-GNB reported worldwide is due to several factors, including the extremely vulnerable patient, the use of immunosuppressive drugs that reduce resistance to infection, frequent use of invasive devices, prolonged hospitalization, and the abuse of broad-spectrum antibiotics (Ha YE et al., 2013; Kaye and Pogue, 2015). This explains our results where all patients infected with MDR have undergone at least two invasive procedures: intubation for $88.88 \%$ of cases, catheterization and urinary catheter for $100 \%$ of them. The infected patients were hospitalized more than 10 days. On the other hand, 26.62\% ( $n$ $=16$ ) of patients are transferred from other services (gastrology, gynecology or traumatology), or have been hospitalized at least once in the current year. An antibiotics treatment has been noted for $90.7 \%$ of the studied cases. Ceftizoxime, cefotaxime were used in $12.24 \%$ of cases, associated with gentamycin or amikacin for $40.81 \%$ or ciprofloxacin for $10.20 \%$ of them. Carbapenems are used in association with an aminoglycoside to treat infections caused by MDR (Table 1).

Table 1: Distribution of MDR-isolated strains related to clinical characteristics of patients.

\begin{tabular}{|c|c|c|c|c|c|c|c|}
\hline \multirow[b]{2}{*}{ Parameter } & \multirow[b]{2}{*}{$\begin{array}{l}E . \text { coli } \\
n=14\end{array}$} & \multicolumn{3}{|c|}{ Fermentative bacteria } & \multicolumn{3}{|c|}{ No-fermentative bacteria. } \\
\hline & & $\begin{array}{c}\text { Klebsiella sp. } \\
\quad n=13\end{array}$ & $\begin{array}{c}\text { Enterobacter sp. } \\
\qquad n=7\end{array}$ & $\begin{array}{c}\text { Serratia sp. } \\
\quad n=4\end{array}$ & $\begin{array}{c}\text { C. freundii } \\
n=3\end{array}$ & $\begin{array}{c}P . \text { aeruginosa } \\
n=5\end{array}$ & $\begin{array}{c}\text { A. baumannii } \\
n=8\end{array}$ \\
\hline \multicolumn{8}{|l|}{ Invasive devices: $n(\%)$} \\
\hline $\begin{array}{l}\text { Urinary catheter } \\
\text { Gastric catheter } \\
\text { Catheterization } \\
\text { Intubation } \\
\text { Ventilation }\end{array}$ & $\begin{array}{c}14(100) \\
2(14.28) \\
14(100) \\
12(85.71) \\
5(35.71)\end{array}$ & $\begin{array}{c}13(100) \\
00 \\
13(100) \\
11(84.61) \\
9(69.23)\end{array}$ & $\begin{array}{c}7(100) \\
00 \\
7(100) \\
7(100) \\
3(42.85)\end{array}$ & $\begin{array}{l}4(100) \\
00 \\
4(100) \\
2(50) \\
2(50)\end{array}$ & $\begin{array}{c}3(100) \\
00 \\
3(100) \\
3(100) \\
2(50)\end{array}$ & $\begin{array}{c}5(100) \\
1(20) \\
5(100) \\
5(100) \\
5(100)\end{array}$ & $\begin{array}{c}8(100) \\
2(25) \\
8(100) \\
8(100) \\
6(75)\end{array}$ \\
\hline \multicolumn{8}{|l|}{ Source: $n(\%)$} \\
\hline $\begin{array}{c}\text { Urine } \\
\text { DPS } \\
\text { RS } \\
\text { Various pus }\end{array}$ & $\begin{array}{c}5(35.71) \\
1(7.14) \\
4(28.57) \\
4(28.57)\end{array}$ & $\begin{array}{c}5(38.46) \\
1(7.69) \\
2(15.38) \\
5(38.46)\end{array}$ & $\begin{array}{l}2(28.57) \\
2(28.57) \\
1(14.28) \\
2(28.57)\end{array}$ & $\begin{array}{c}1(25) \\
1(25) \\
00 \\
2(50)\end{array}$ & $\begin{array}{c}2(66.66) \\
00 \\
1(33.33) \\
00\end{array}$ & $\begin{array}{c}1(20) \\
2(40) \\
00 \\
2(40)\end{array}$ & $\begin{array}{c}2(25) \\
00 \\
00 \\
6(75)\end{array}$ \\
\hline \multicolumn{8}{|l|}{ Previous antibioticsuse: $n(\%)$} \\
\hline $\begin{array}{c}\text { C3G } \\
\text { C3G + aminoglycoside } \\
\text { C3G + fluoroquinolone } \\
\text { Aminosides }+ \text { fluoroquinolone } \\
\text { Carbapenems +aminoside } \\
\text { Aminoside }\end{array}$ & $\begin{array}{l}2(15.38) \\
5(35.71) \\
1(7.14) \\
1(7.14) \\
00 \\
2(15.38)\end{array}$ & $\begin{array}{c}2(15.38) \\
1(7.69) \\
1(7.69) \\
1(7.69) \\
1(7.69) \\
4(30.76)\end{array}$ & $\begin{array}{c}1(14.28) \\
6(85.71) \\
00 \\
00 \\
00 \\
00\end{array}$ & $\begin{array}{c}00 \\
1(25) \\
1(25) \\
1(25) \\
00 \\
00\end{array}$ & $\begin{array}{c}1(33.33) \\
1(33.33) \\
00 \\
00 \\
00 \\
1(33.33)\end{array}$ & $\begin{array}{c}00 \\
1(20) \\
1(20) \\
00 \\
4(80) \\
00\end{array}$ & $\begin{array}{c}00 \\
5(62.5) \\
1(12.5) \\
00 \\
3(37.5) \\
00\end{array}$ \\
\hline
\end{tabular}

$\mathrm{DPS}=$ distal protected sampling; $\mathrm{RS}=$ rectal swab; $\mathrm{C} 3 \mathrm{G}=$ third-generation cephalosporin .

However, other authors also report the important role of inanimate surfaces in the spread of resistant bacteria and the emergence of nosocomial infection (Zenati et al., 2016).

The most isolated MDR are Enterobacteriaceae $(n=41$, $75.92 \%)$, especially $E$. coli and Klebsiella sp. $(n=27 / 41)$ followed by Enterobacter $(n=7 / 41)$, Serratia $(n=4 / 41)$ and Citrobacter $(n=3 / 41)$. The other MDR group constitutes of the NF-GNB, particularly A. baumannii $(n=8,14.81 \%)$ and $P$. aeruginosa $(n$ $=5,9.25 \%$ ), which represent $24.07 \%$ of MDR isolates. These results have been previously reported by other studies in Annaba city (Mellouk et al., 2017). Our findings are also correlated to other studies in Gulf countries (Aly and Balkhy, 2012) and India (Silpi et al., 2016). While another study in a tertiary care hospital in Riyadh city (KSA), reported that the most common isolate pathogens are $P$. aeruginosa, $A$. baumannii followed by $E$. coli and K. pneumoniae (Aljohani et al., 2010). The multidrug- resistant strains of $P$. aeruginosa $(n=5)$ have been isolated mainly from pus but also from urine and DPS, A. baumannii strains ( $n=$ 8 ) were isolated exclusively from various pus.

\section{Antimicrobial susceptibility testing}

\section{Fermentative bacteria}

The results of the antibiotic susceptibility testing for Enterobacteriaceae revealed an increased resistance to fluoroquinolones, exceeding $60 \%$ for ciprofloxacin, which is the main antibiotic used for the treatment of urinary infections specifically caused by $E$. coli. Resistance to the majority of tested $\beta$-lactams showed high rates: 100\% (cefotaxime), 85.36\% (ceftriaxone), $75.60 \%$ (amoxicillin/clavulanic acid), 68.29\% (ceftazidime) and $53.65 \%$ (aztreonam). All these molecules represent the antibiotics of choice for treating infections in this department. Resistance rate 
to other classes of antibiotics was $24.39 \%, 56.09 \%$ to amikacin and gentamycin respectively. However, the isolates remain sensitive to imipenem, colistin, and tigecycline.

Resistance to carbapenems has been recorded only for two strains with a MIC value ranging from 4 to $8 \mu \mathrm{g} / \mathrm{ml}$ for ertapenem (the carbapenem that has the best sensitivity for the detection of EPCs especially OXA-48) but it was not possible to demonstrate the production of carbapenemases by biochemical tests. Details of antimicrobial susceptibility testing are demonstrated in Figure 1.

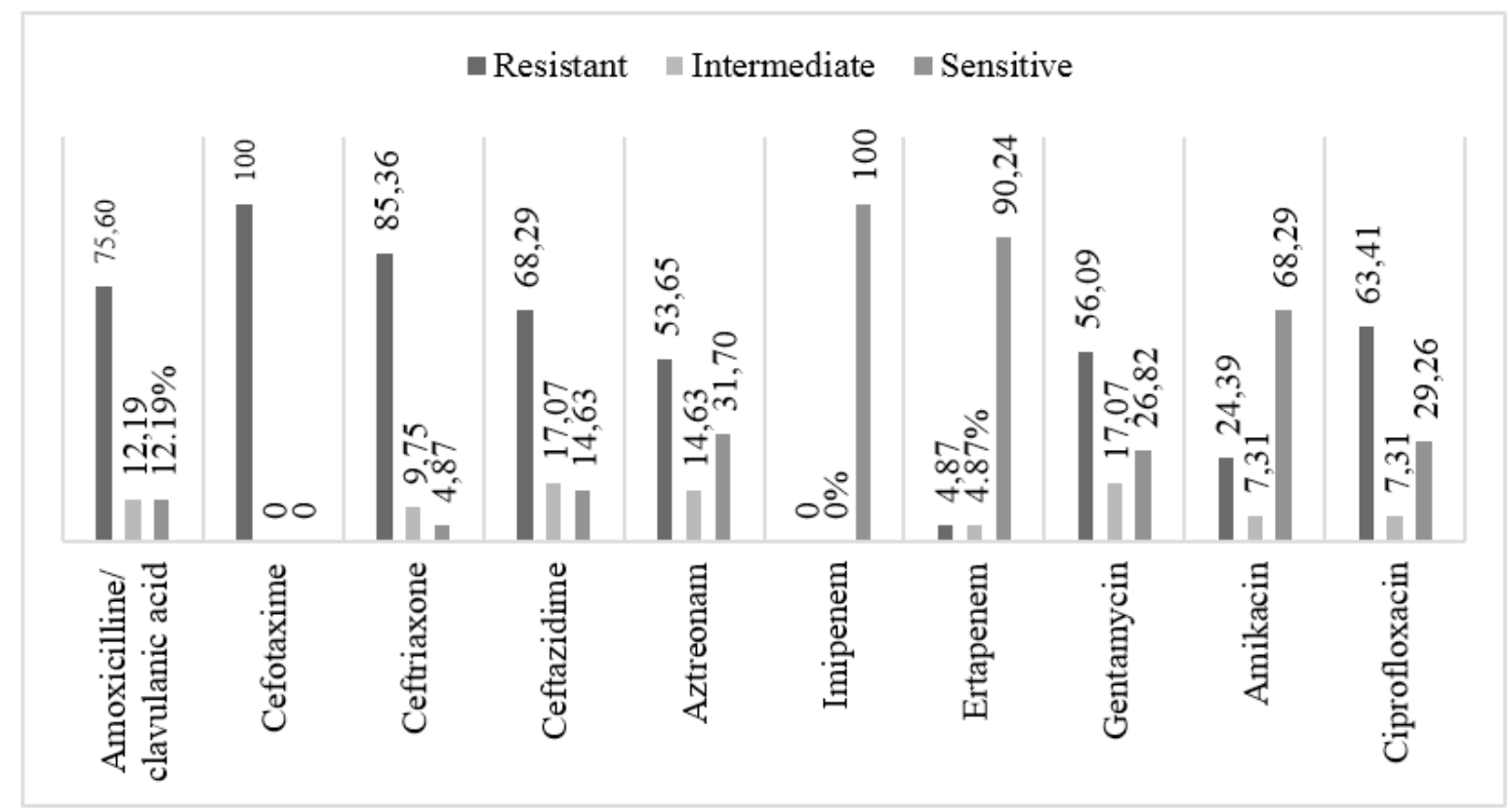

Fig. 1: Antimicrobial susceptibility of multi-drug-resistant Enterobacteriaceae isolates.

Enterobacter $s p$. and $S$. marcescens isolated strains are relatively few but they showed the highest rates of resistance for the majority of tested antibiotics.

Algeria considered as a country with a high epidemic of ESBL, where their prevalence in intensive care unit has increased from $43.73 \%$ in 2014 to $44.16 \%$ in 2015 according to Algerian network for surveillance the resistance of bacteria to antibiotics report's (AARN, 2014-2015). In our study Enterobacteriaceae producing ESBL is detected for $11.47 \%$ of a total of strains $(n=$ $14 / 122 ; 34.14 \%$ for MDR isolates) which is comparatively lower than Tlemcen (Algeria) (32.1\%) (Ahmed et al., 2012) and Burkina Faso (58\%) (Ouedraogo et al., 2016). Many studies reported that E.coli is the main ESBL producing followed by K. pneumoniae, which is clearly increasing (Ouedraogo et al., 2016). Other study revealed the predominance of $K$. pneumonia (Dropa et al., 2009). Our findings revealed that the number of $E$. coli producing ESBL ( $n=6,42.85 \%)$ is the same as that of $K$. pneumoniae ( $n=6$, $42.85 \%)$ followed by Serratia sp. ( $n=2,14.28 \%)$. These ESBL producing Enterobacteriaceae comes from urine samples (6/14), rectal swabs (3/14), DPS (3/14) and pus (2/14).

The question that arises is how to identify the grouped cases of cross-transmission or linked to an environmental reservoir. In this case, molecular typing on positive ESBL isolates from infected or colonized patients is needed to determine the clonal distribution (Ha YE et al., 2013).

The existence of ESBL bacteria is more commonly associated with the resistance to other classes of antibiotics such as fluoroquinolones, as shown in our study where $58.33 \%$ of ESBLs are resistant to ciprofloxacin. Plasmid gene transfer (Qnr) has been reported in Enterobacteriaceae isolates simultaneously producing ESBL, by several authors in Annaba city, Algeria (Meradi et al., 2011). The lowest rates of co-resistance are recorded for ertapenem $(8.33 \%)$, whereas highest level noted for amikacin $(33.33 \%)$.

The production of ESBL is associated with the elaboration of cephalosporinases for $17.07 \%$ of strains, revealed by the cloxacillin test.Only36.58\% $(n=15)$ of studied MDR strains were found to be AmpC $\beta$-lactamases producers.

\section{Non-fermentative - Gram-negative bacilli}

$P$. aeruginosa and $A$. baumannii are the most NF-GNB studied because of their higher isolation rates and their increased resistance to almost all available antimicrobials. The isolates obtained in the current study showed different levels of resistance to the antimicrobial agents. The MIC values are high for the $\beta$-lactams family, ranging from 16 to $128 \mu \mathrm{g} / \mathrm{ml}$ for imipenem and meropenem, $>16 \mu \mathrm{g} / \mathrm{ml}$ for aztreonam, $>64 \mu \mathrm{g} / \mathrm{ml}$ for ticarcillin, $>32 \mu \mathrm{g} / \mathrm{ml}$ for ceftazidime, $>16 \mu \mathrm{g} / \mathrm{ml}$ for cefepime, $>32 \mu \mathrm{g} / \mathrm{ml}$ for amikacin, $>2$ $\mu \mathrm{g} / \mathrm{ml}$ for ciprofloxacin. They had sensitivity only to polymyxin-E $(2 \mu \mathrm{g} / \mathrm{ml})$ and tigecycline (A. baumannii $\mathrm{MIC}=1-2 \mu \mathrm{g} / \mathrm{ml})$, which limits then the antibiotherapeutic possibilities and increases the costs of care and mortality rate (Al Johani et al., 2010).

The emergence of imipenem-resistant $A$. baumannii (IRAB) has become a universal concern, as these molecules are often the only effective treatment against these strains (Otéo et al., 
2007). In our study the imipenem resistance rate is $80 \%(n=8 / 10)$, which is similar to results found in Iran ( $>80 \%$ ) (Mohajeri et al., 2017) and Algeria (75.2\%) (Khorsi et al., 2015), significantly higher than those reported in Saudi Arabia (5.4\%) (Memish et al., 2012).

$P$. aeruginosa has a sensitivity rate of $75 \%$ to imipenem ( $n=15 / 20$ ); this value is comparable to that reported in Egypt (73.5\%) (Hashem et al., 2017). Higher than that reported in Iran (4\%) (Saffari et al., 2016), a little higher than that reported in another study in Annaba city (50\%) (Meradji et al., 2016) and a study in western Algeria between 2009 and 2012 (39.32\%) (Sefraoui et al., 2014).

Among these strains $43.33 \%(n=13 / 30)$ are resistant to carbapenems, only two strains of $P$. aeruginosa $(n=2 / 20,10 \%)$ are positive for production of carbapenemases by both MHT and MBL screen, these enzymes are detected in $80 \%(n=8 / 10)$ of
A. baumannii isolates. Both MHT and MBL screen were positive only for one strain of them. No strain of them produced ESBL.

\section{Resistance gene determination}

Several studies have identified a variety of oxacillinases in carbapenem-resistant $A$. baumannii. The bla ${ }_{O X A-23}$ gene was reported worldwide, the $b l a_{O X A-24}, b l a_{O X A-72,}$ and bla ${ }_{O X A-58}$ genes were described later (Pogue et al., 2013). In Algeria, bla OXA-23 $_{2}$ and $b l a_{O X A-24}$ were reported by touati et al. from patients hospitalized in the intensive care units (2012), bla $a_{O X A-24}$ and bla $a_{O X A-72}$ reported in Setif, bla $a_{O X A-23}$ in Tizi-Ouzou (Bakour et al., 2012), bla $a_{O X A-23}$ and bla $_{O X A-24}$ in Tlemcen, Oran and Algiers (Mesli et al., 2013; Khorsi et al., 2015). The bla ${ }_{O X A-23}$ gene was founded in six strains of $A$. baumannii resistant to imipenem $(60 \%)$ while the $b_{\text {OXA-24 }}$ was described only for one isolate (10\%) Table 2.

Table 2: Genes encoding carbapenemases of $P$. aeruginosa and $A$. baumannii isolates.

\begin{tabular}{|c|c|c|c|c|c|c|}
\hline Strains & Sexe/Age & Source & Diagnostic & Antibiotics use & CMI/IMP $(\mu \mathrm{g} / \mathrm{ml})$ & Genes \\
\hline$P$. aeruginosa & $\mathrm{M} / 27$ & pus & traumatic brain injury & $\begin{array}{l}\text { - ceftizoxime, gentamycine } \\
\text { - imipenem, amikacin }\end{array}$ & 128 & VIM-2 \\
\hline P. aeruginosa & $\mathrm{M} / 50$ & DPS & polytrauma & $\begin{array}{c}\text { - ceftizoxime, gentamycine } \\
\text { - imipenem, gentamicine } \\
\text { vancomycine }\end{array}$ & 128 & VIM-2 \\
\hline A. baumannii & $\mathrm{M} / 36$ & DPS & peritonitis & $\begin{array}{c}\text { - ceftizoxime, gentamycine } \\
\text { - imipenem, gentamicine } \\
\text { Vancomycine }\end{array}$ & 16 & OXA-23 \\
\hline A. baumannii & $\mathrm{M} / 25$ & pus & traumatic brain injury & $\begin{array}{l}\text { - ceftizoxime, metronidazol } \\
\text { - cefotaxime, ciprofloxacine, gentamycine }\end{array}$ & 16 & OXA-23 \\
\hline A. baumannii & $\mathrm{M} / 19$ & pus & hemorrhagic pulmonary contusion & - ceftizoxime, gentamicine & 32 & OXA-23 \\
\hline A. baumannii & $\mathrm{F} / 41$ & pus & polytrauma & - cefotaxime, gentamicine & 16 & OXA-23 \\
\hline A. baumannii & $\mathrm{F} / 53$ & DPS & escarre & - ceftizoxime, ciprofloxine, metronidazol & 16 & OXA-23 \\
\hline A. baumannii & $\mathrm{M} / 65$ & AT & insufficiency renal & - imipenem & 16 & OXA-23 \\
\hline A. baumannii & $\mathrm{F} / 32$ & $\mathrm{AT}$ & post-surgery coma & $\begin{array}{c}\text { - ceftizoxime, gentamycine } \\
\text { - tienam, gentamicine } \\
\text { vancomycine }\end{array}$ & 16 & OXA-24 \\
\hline A. baumannii & $\mathrm{M} / 21$ & AT & polytrauma & $\begin{array}{l}\text { - ceftizoxime, metronidazol } \\
\text { - cefotaxime, ciprofloxacine, gentamycine }\end{array}$ & 64 & NDM-1 \\
\hline
\end{tabular}

$\mathrm{DPS}=$ distal protected sampling; AT = aspiration tracheal.

New Delhi MBL (NDM-1) has been mostly detected in $K$. pneumoniae and $E$. coli clinical isolates and lower in Pseudomonas sp. and Acinetobacter sp. The first description of this enzyme in $A$. baumannii in Algeria was reported by Boulanger et al. (2012), Bogaerts et al. (2012) and then reported by Bakour et al. (2012), Mesli et al. (2013), and Khorsi et al. (2015). Recently, this gene was detected for the first time in Algeria in Acinetobacter nosocomialis isolates in Ouargla city (Yagoubat et al., 2017); in this study, the $b l a_{N D M-1}$ gene was only detected in one isolate of $A$. baumannii (Table 2).

In this study, two $P$. aeruginosa strains harbor bla $a_{V I M-2}$ (MBL) (Table 2), which is the most frequently isolated gene in this bacteria, previously identified in Annaba (Touati et al., 2013; Meradji et al., 2016) and Oran (Sefraoui et al., 2014). The bla gene was reported by Mellouk et al. (2017) and Meradji et al. (2016) in the burns department. Recapitulative of carbapenemases genes detected in non-fermentative bacteria in Algeria is presented in Table 3.

The strains of $P$. aeruginosa resistant to imipenem but non-productive of carbapenemases may be attributed to OprD mutations, but this mechanism is not limited only to Carbapenemresistant isolates, but also for the isolates with MIC of only 0.06 to $4 \mu \mathrm{g} / \mathrm{ml}$ of imipenem or meropenem. The phenomenon of efflux ad can be also mentioned. 
Table 3: Carbapenemases genes of Acinetobacter sp. and Pseudomonas aeruginosa detected in Algeria.

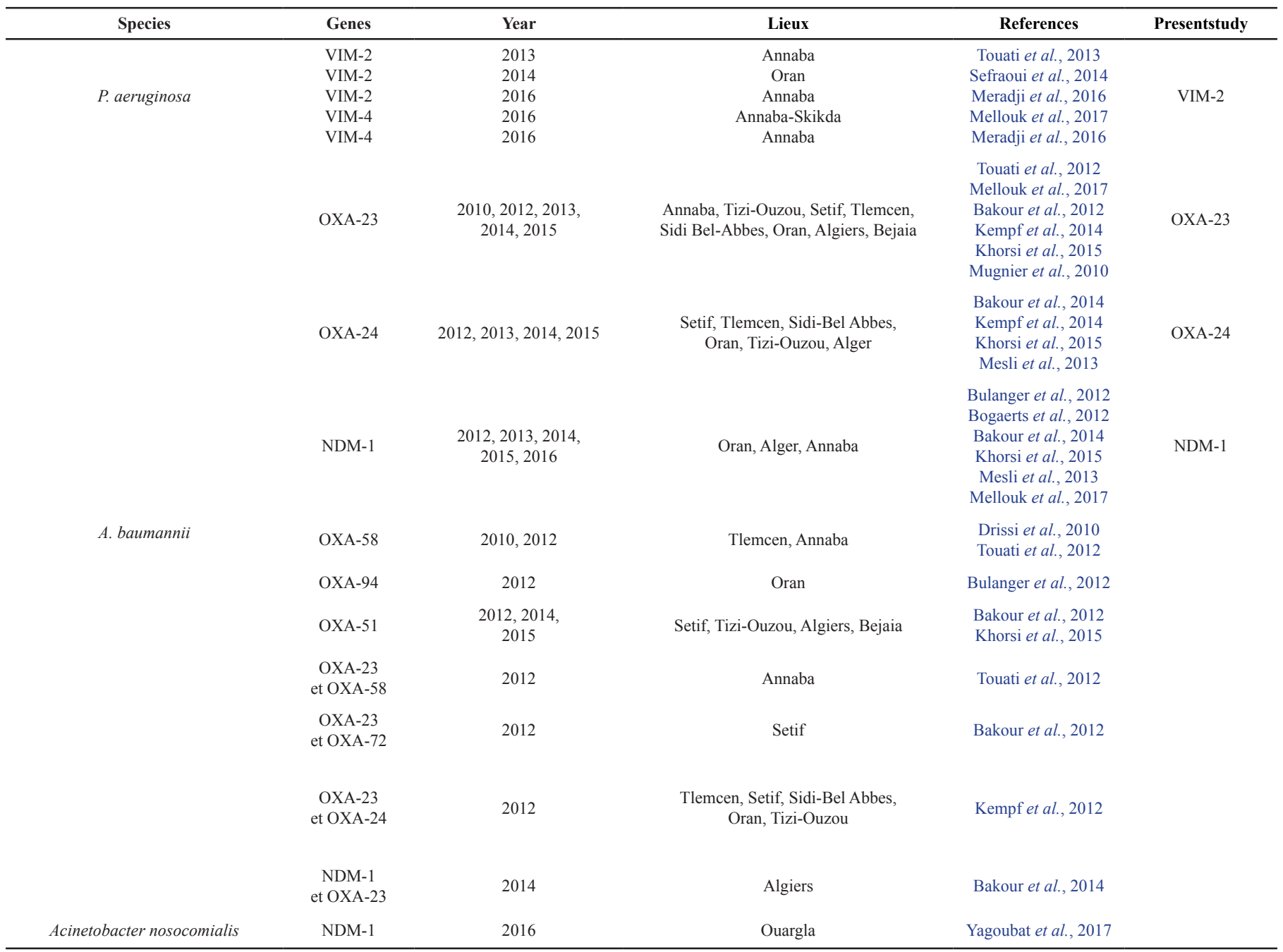

\section{CONCLUSION}

The intensive care unit in Ibn Rochd hospital shows a high prevalence of MDR (more than a third of isolates are MDR). This situation is probably due to the higher rate, excessive and inappropriate use of antimicrobials; making infections more difficult to treat and increases the cost and duration of hospitalization. $E$. coli, $K$. pneumoniae, $P$. aeruginosa and A. baumannii are the most frequent incriminated infections MDR-GNB agent in this structure harboring a various genes encoding for oxacillinases and metallo$\beta$-lactamases. The situation is worrying that could lead to outbreaks of epidemic resistance because they are carried by mobile genetic elements easily transferable between Gram-negative species. Some measures must be taken, to slow down the rising problem of MDR especially; rational use of antibiotics and infection control to prevent any potential epidemic risk.

\section{CONFLICT OF INTEREST}

None.

\section{REFERENCES}

Ahmed ZB, Ayad A, Mesli E, Messai Y, Bakour R, Drissi M. CTX-M-15 extended-spectrum $\beta$-lactamases in Enterobacteriaceae in the intensive care unit of Tlemcen Hospitals, Algeria. East Mediterr Health J, $2012 ; 18: 382-6$

Algerian network for surveillance the resistance of bacteria to antibiotics (AARN). 2014-2015. Surveillance of antibiotic resistance. 13 $3^{\text {th }}$ and $16^{\text {th }}$ evaluation report.

AlJohani SM, Akhter J, Balkhy H, El-Saed A, Younan M, Memish Z. Prevalence of antimicrobial resistance among gram-negative isolates in an adult intensive care unit at a tertiary care center in Saudi Arabia. Ann Saudi Med, 2010; 30:364-9.

Aly M, Balkhy HH. The prevalence of antimicrobial resistance in clinical isolates from Gulf Corporation Council countries. Antimicrob Resist Infect Control, 2012; 1(1):26.

Arsalane L, Qamouss, Chafik A, Boughalem M, Louzi L. Epidémiologie des bactéries multirésistantes dans un service de réanimation polyvalente d'un hôpital universitaire de Marrakech entre octobre 2006 et septembre 2009. Les Technologies De Laboratoire, 2010; 5:21.

Baba Ahmed-Kazi Tani Z, Arlet G. Actualité de la résistance aux antibiotiques chez les bacilles à Gram négatif en Algérie. Pathologie Biologie, 2014; 62:169-178.

Bakour S, Kempf M, Touati A, Ait AA, Haouchine D, Sahli F, Rolain JM. Carbapenemase-producing Acinetobacter baumannii in two university hospitals in Algeria. J Med Microbial, 2012; 61:1341-3.

Bakour S, Touati A, Bachiri T, Sahli F, Tiouit D, Naim M, Azouaou M, Rolain JM. First report of 16s rRNA methylase ArmAproducing Acinetobacter baumannii and rapid spread of metallo-beta- 
lactamase NDM-1 in Algerian hospitals. J. infect. Chemother, 2014; 20:696-701.

Bogaerts P, Rezende de Castro R, Roisin S, Deplano A, Huang T-D, Hallin M, Denis O, Glupczynski Y. Emergence of NDM-1-producing Acinetobacter baumannii in Belgium. J Antimicrob Chemother, 2012; 67: 1552-3.

Boulanger A, Naas T, Fortineau N, Figueiredo S, Nordmann P. NDM-1-producing Acinetobacter baumannii from Algeria. Antimicrob Agents Chemother, 2012; 56: 2214-5.

Drieux L, Brossier F, Sougakoff W, Jarlier V. Phenotypic detection of extended-spectrum beta-lactamase production in Enterobacteriaceae: review and bench guide. Clin Microbiol Infect, 2008; 14 suppl 1:90-103.

Drissi M, Poirel L, Mugnier P.D, Baba Ahmed Z, Nordmann P. Carbapenemase-producing Acinetobacter baumannii, Algeria. Eur. J. Clin. Microbiol, 2010; 29: 1457-1458.

Dropa M, Balsalobre LC, Lincopan N, Mamizuka EM, Murakami T, Cassettari VC, Franco FF, Guida SM, Balabakis AJ, Passadore LF, Santos SR, Matté GR, Matté MH. Extended-spectrum beta-lactamases among Enterobacteriaceae isolated in a public hospital in Brazil. Rev Inst Med trop. Sao Paulo, 2009; 51:203-9.

Esther J, Edwin D, Uma. Prevalence of Carbapenem Resistant Non-Fermenting Gram Negative Bacterial infection and identification of Carbapenemase Producing NFGNB Isolates by Simple Phenotypic Tests. J Clin Diagn Res, 2017; 11:10-13.

Gupta SK, Padmanabhan BR, Diene SM, Lopez-Rojas R, Kempf M, Landraud L, Rolain JM. ARG-ANNOT, a new bioinformatic tool to discover antibiotic resistance genes in bacterial genomes. Antimicrob. Agents Chemother, 2014; 58:212-220.

Hashem H, Hanora A, Abdalla S, Shaeky A, Saad A Dissemination of metallo- $\beta$-lactamase in Pseudomonas aeruginosa isolates in Egypt: mutation in bla $a_{V I M-4}$. APMIS, 2017; 125:499-505.

Ha YE, Kang C-I, Cha MK, Park SY, Wi YM, Chung DR, Peck KR, Lee NY, Song JH. Epidemiology and clinical outcomes of bloodstream infections caused by extended-spectrum b-lactamase-producing Escherichia coli in patients with cancer. Int J Antimicrob Agents, 2013; 42:403-409.

Kaye KS, Pogue JM. Infections Caused by Resistant GramNegative Bacteria: Epidemiology and Management. Pharmacotherapy, 2015; 35:949-62.

Kempf M, Bakour S, flaudrops C, Berrazeg M, Brunel J.M, Drissi M, Touati A, Rolain JM. Rapid detection of carbapenem resistance in Acinetobacter baumannii using matrix-assisted laser desorption ionizationtime of flight mass spectrometry. PLos One, 2012; 7:e31676.

Khorsi K, Messai Y, Hamidi M, Ammari H, Bakour R. High prevalence of multidrug-resistance in Acinetobacter baumannii and dissemination of carbapenemase-encoding genes $b l a_{O X A-23}$-like, bla $_{O X A-24}$-like and $b l a_{N D M-1}$ in Algiers hospitals. Asian Pac J Trop Med, 2015; 8:438-446.

McGowan JE Jr. Resistance in non-fermenting Gram-negative bacteria: multidrug resistance to the maximum. Am J Med, 2006; 119:29-36.

Mellouk FZ, Bakour S, Meradji S, Al-Bayssari C, Bentakouk MC, Zouyed F, Djahoudi A, Boutefnouchet N, Rolain JM. First Detection of VIM-4-Producing Pseudomonas aeruginosa and OXA-48-Producing Klebsiella pneumoniae in Northeastern (Annaba, Skikda) Algeria. Microb Drug Resist, 2017; 23:335-344.

Memish ZA, Shibl AM, Kambal AM, Ohaly YA, Ishaq A, Livermore DM. Antimicrobial resistance among non-fermenting Gram-negative bacteria in Saudi Arabia. J Antimicrob Chemother, 2012; 67:1701-1705.

Meradi L, Djahoudi A, Abdi A, Bouchakour M, Perrier Gros Claude JD, Timinouni M. Qnr and aac(6')-Ib-cr types quinolone resistance among Enterobacteriaceae isolated in Annaba, Algeria. Pathol Biol, 2011; 59:73-78.

Meradji S, Barguigua A, Bentakouk MC, Nayme K, Zerouali K, Mazouz D, Chettibi H, Timinouni M. Epidemiology and virulence of VIM4 metallo-beta-lactamase-producing Pseudomonas aeruginosa isolated from burn patients in eastern Algeria. Burns, 2016; 42:906-18.

Mesli E, Berrazeg M, Drissi M, Bekkhoucha SN, Rolain JM Prevalence of carbapenemase-encoding genes including New Delhi metallo-beta-lactamase in Acinetobacter species, Algeria. Int J Infect Dis, $2013 ; 17: 739-43$

Mohajeri P, Farahani A, Mehrabzadeh RS. Molecular Characterization of Multidrug Resistant Strains of Acinetobacter baumannii Isolated from Intensive Care Units in West of Iran. J Clin Diagn Res, 2017; 11:20-22.

Mugnier P.D, Poirel L, Naas T, Nordmann P. Worldwide dissemination of the blaOXA-23 carbapenemase gene of Acinetobacter baumannii. Emerg. Infect. Dis, 2010; 16:35-40.

Otéo J, Garcia-Estebanez C, Miguelanez S, Campos J, Marti S, Vila J, Dominguez MA, Docobo F, Larrosa N, Pascual A, Pintado V, Coll P. Genotypic diversity of imipenem resistant isolates of Acinetobacter baumannii in Spain. The Journal of Infection, 2007; 55:260-266.

Ouedraogo AS, Sanou M, Kissou A, Sanou S, Solaré H, Kaboré F, Poda A, Aberkane S, Bouzinbi N, Sano I, Nacro B, Sangaré L, Carriere C, Decré D, Ouégraogo R, Jean-Pierre H, Godreuil S. High Prevalence of Extended-Spectrum-B-Lactamases Producing Enterobacteriaceae among Clinical Isolates in Burkina Faso. BMC Infect Dis, 2016; 16:326.

Pogue JM, Mann T, Barber KE, Kaye KS. Carbapenem-resistant Acinetobacter baumannii: epidemiology, surveillance and management. Expert Rev Anti Infect Ther, 2013; 11:383-93.

Poirel L, Dortet L, Nordmann P. Épidémiologie des carbapénémases Current epidemiology of carbapenemases. La Lettre de l'Infectiologue, 2013; 4:124-127.

Régnier B. Bacteria, Multiresistant to Antibiotics in Intensive Care Units: Epidemiological Context and Strategies of Control. Pathol Biol, 1996; 44:113-123.

Rodriguez-Martinez JM, Poirel L, Nordmann P. Molecular epidemiology and mechanisms of carbapenem resistance in Pseudomonas aeruginosa. Antimicrob Agents Chemother, 2009; 53:4783-8.

Saffari M, Firoozeh F, Pourbabaee M and Zibaei M. Evaluation of Metallo- $\beta$-Lactamase-Production and Carriage of $b l a_{V I M}$ Genes in Pseudomonas aeruginosa Isolated from Burn Wound Infections in Isfahan. Arch Trauma Res, 2016; 5:e34343.

Sefraoui I, Berrazeg M, Drissi M, Rolain JM. Molecular epidemiology of carbapenem-resistant Pseudomonas aeruginosa clinical strains isolated from western Algeria between 2009 and 2012. Microb Drug Resist, 2014; 20:156-61.

Silpi B, Priyanka S, Monali R. Multidrug Resistant and Extensively Drug Resistant Bacteria: A Study. J Pathog, 2016; 2016: 4065603, 5p.

Touati M, Diene SM, Racherache A, Dekhil M, Djahoudi A, Rolain JM. Emergence of $b l a_{O X A-23}$ and $b l a_{O X A-58}$ carbapenemase-encoding genes in multidrug-resistant Acinetobacter baumannii isolates from University Hospital of Annaba, Algeria. Int. J. Antimicrob Agents, 2012; 40:89-91.

Touati M, Seydina MD, Dekhil M, Djahoudi A, Racherache A, Rolain JM. Dissemination of a Class I Integron Carrying VIM-2 Carbapenemase in Pseudomonas aeruginosa Clinical isolates from a Hospital Intensive Care Unit in Annaba, Algeria. Antimicrob Agents Chemother, 2013; 57:2426-2427.

Yagoubat M, Ould El-Hadj-Khelil A, Malki A, Bakour S, Touati A, Rolain JM .Genetic characterization of carbapenem-resistant Gramnegative bacteria isolated from the University Hospital Mohamed Boudiaf in Ouargla, southern Algeria. J Glob Antimicrob Resist, 2017; 8:55-59.

Zenati K, Touati A, Bakour S, Sahli F, Rolain JM. Characterization of NDM-1- and OXA-23-producing Acinetobacter baumannii isolates from inanimate surfaces in a hospital environment in Algeria. J Hosp Infect, 2016; 92:19-26.

How to cite this article:

Toumi S, Meliani S, Amoura K, Rachereche A, Djebien M, Djahoudi A. Multidrug-resistant Gram-negative bacilli producing oxacillinases and Metallo- $\beta$-lactamases isolated from patients in intensive care unit - Annaba hospital - Algeria (20142016). J App Pharm Sci, 2018; 8(07): 107-113. 